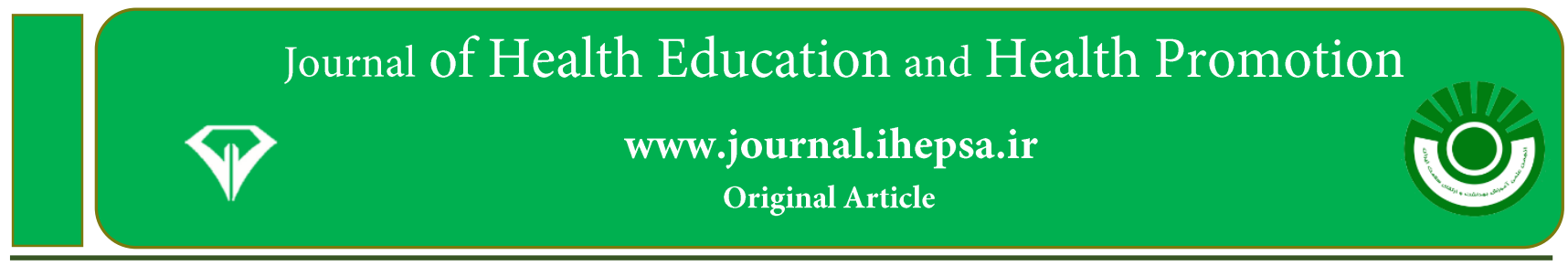

\title{
Indigenization of Healthy Workplace Model of World Health Organization: A Participatory Approach
}

\author{
Ensiyeh Jamshidi', Khandan Shahandeh', Masoud Motalebi Ghaen ${ }^{2}$, Fatemeh Rajabi \\ Ali Moradi ${ }^{4}$, Mohammad Hosein Taghdisi
}

1. Dept. of Health Education and Health Promotion, Community Health Research Center, Risk-Detection Research Center, Tehran University of Medical Sciences, Tehran, Iran

2. Dept. of Health Education and Health Promotion, School of Public Health, Iran University of Medical Sciences, Tehran, Iran

3. Social Medicine Specialist, Tehran University of Medical Sciences, Tehran, Iran

4. Dept. of Statistics and Epidemiology, Shahid Beheshti University of Medical Sciences, Tehran, Iran

\section{Article Information}

\section{Article History:}

Received: 2017/08/30

Accepted: 2018/02/26

Available online: 2018/01/30

\section{IJHEHP 2018; 6(1):080-094}

DOI:

Corresponding Author:

\section{Dr. Khandan Shahandeh}

Dept. of Health Education and

Health Promotion, Community

Health Research Center, Risk-

Detection Research Center,

Tehran University of Medical

Sciences, Tehran, Iran

Tel: 0982181633634

Email:

kshahandeh@gmail.com

Use your device to scan

and read the article online

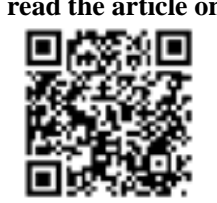

\section{Abstract}

Background and Objective: Healthy workplace models that have been used in the country merely appraised the situation of workplaces and were less practical and participative. The aim of this study is to indigenize the world health organization health promoting workplace model.

Methods: Indigenization of the world health organization healthy workplace model to develop assessment tool for healthy work place were conducted in 3 phases. In preparation phase, checklist for assessment of different dimensions of the healthy workplace was prepared. In second phase, a practical guideline for application of model was developed and in third phase, the adaptation plan finalized draft of checklist and practical guideline was finalized through a joint meeting of panel members and representatives of the end users.

Results: Situation of industrial workplaces in the country was considered in adaptation approach. Assessment tool for different dimensions of the healthy workplace including the physical work environment, the psychosocial work environment, the health resources and the enterprise involvement in the community and the practical guideline were finalized.

Conclusion: Developed assessment tool for healthy workplace model and the practical guideline can be used by policy makers and planners.

KeyWords: Health Promotion, Healthy ,Workplace ,Model.

How to cite this article:

Jamshidi E, Shahandeh K, Motalebi Ghaen M, Rajabi F, Moradi A, Taghdisi M H. Indigenization of Healthy Workplace Model of World Health Organization: A Participatory Approach. Iran J Health Educ Health Promot. 2018; 6 (1) : 80-94

Jamshidi E, Shahandeh K, Motalebi Ghaen M, Rajabi F, Moradi A, Taghdisi M H. Indigenization of Healthy Workplace Model of World Health Organization: A Participatory Approach. Iran J Health Educ Health Promot. 2018; 6 (1) : 80-94 
بومىسازى مدل محيط كار ارتقادهندة سلامت سازمان بهداشت جهانى با رويكرد مشاركتى

انسيه جمشيدى'، خندان شاهنده'، مسعود مطلبى قائن'، فاطمه رجبى"، على مرادى'، محمدحسين تقديسى'

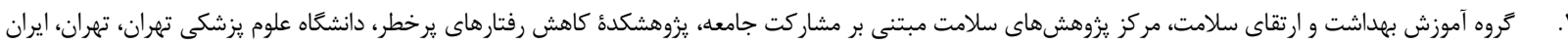

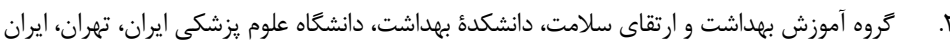

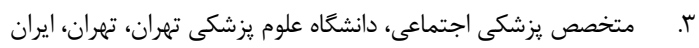

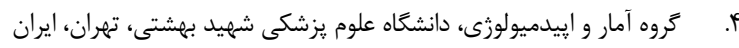

زمينه و هدف: مدلهاى ارزيابى محيطهاى كار كه در كشور به كار كرفتهشدهاند، جنبهُ كاربردى و مشاركتى

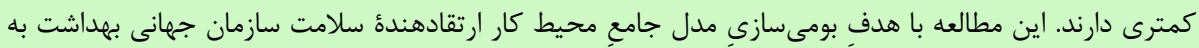
شيؤ مشاركتى انجام كرفته است. مواد و روشىها: فرايند بومىسازى مدل محيط كار ارتقادهندة سلامت در سه مرحله انجام شد. در مرحلئ اول

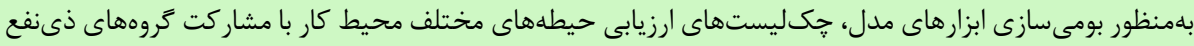

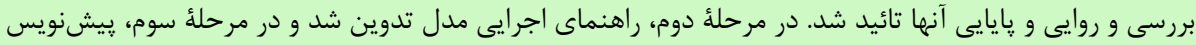

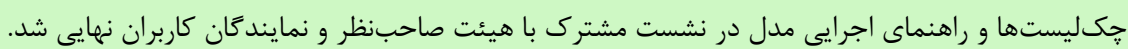
يافته ها: مجموعه نظرات شركت كنندكان سبب شد كه شرايط محيطهاى كار صنايع ايران در ابزار ارزيابى محيط

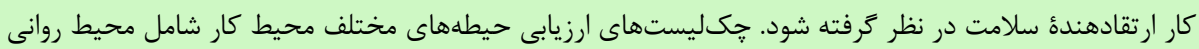

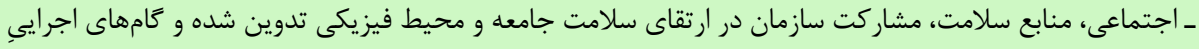

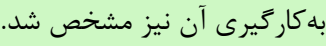
نتيجه كيرى: راهنماى مدل محيط كار ارتقادهنده سلامت و ابزارهاى ارزيابى حيطههاى محيط كار مىتوانند در

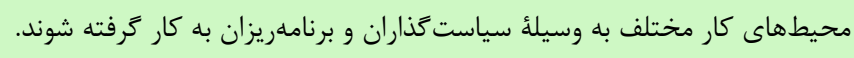
كلمات كليدى: ارتقاى سلامت، سلامت،محيط كار، مدل. كيىرايت (؟): حق :اب، نشر و استفادة علمى از اين مقاله براى مجلئ آموزش بهداشت و ارتقاى سلامت محفوظ است.

اطلاعات مقاله - - اله

تاريخجٌهُ مقاله

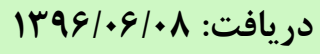

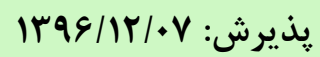

انتشار آنلاين: •|/||

\section{IJHEHP 2018; 6(1):080-094}

نويسندهُ مسئول:

دكتر خندان شاهنده

كروه آموزش بهداشت و ارتقاى سلامت، مركز يزوهشهاى سلامت مبتنى بر مشاركت جامعه،

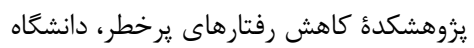

علوم يزشكى تهران، تهران، ايران

تلفن:

يست الكترونيك:

kshahandeh@gmail.com

براى دانلود اين مقاله، كد زير را

با موبايل خود اسكن كنيد.

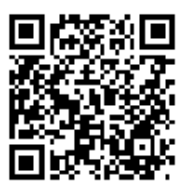

\section{مقلممه}

(ץ-Y). در همين راستا و به دليل امكان دسترسى به درصد بالايى از جمعيت فعال، خطمشى و برنامئ اصلى شركتهاى موفق ريق

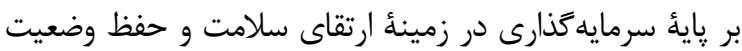
ايدئال براى كاركنان استوار است (و،هائه).
محيطهاى ارتقادهندة سلامت، يكى از محورهاى

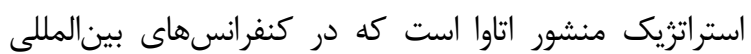
ارتقاى سلامت بهصورت عملياتى به آن برداختهاند و الزام آن براى دولتها مطرحشده است (1). يروهشهاى متعدد نشان مىدهد كه ارتقاى سلامت در محيط كار موجب كاهش رفتارهاى ناسالم

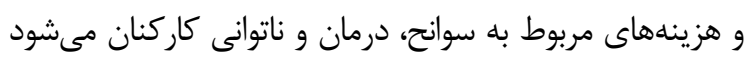


جامع محيط كار ارتقادهنده سلامت سازمان جهانى بهداشت و تدوين راهنماى اجرايى آن است.

$$
\text { روش بررسى }
$$

فرايند بومىسازى مدل محيط كار ارتقادهندة سلامت

$$
\text { از سه مرحله تشكيل شده است. }
$$

\section{بومىسازى ابزار ارزيابى محيط كار ارتقادهنده سلامت}

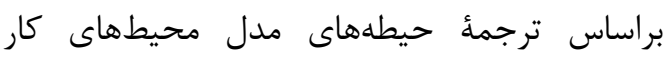

ارتقادهنده سلامت و راهنماى جامع ارزيابى اركونوميك كار

(•)، كويههاى مرتبط با קكليستهاى ارزيابى در קهار حيطهُ محيط فيزيكى، محيط روانى ـ اجتماعى، مسئوليت

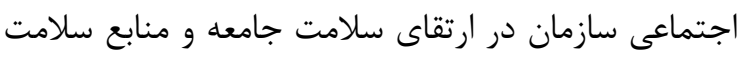
تهيه شد. اين קكليستها را هيئتى از متخصصان (جهار

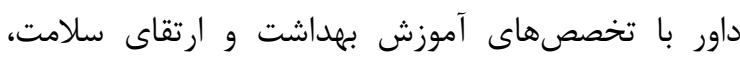

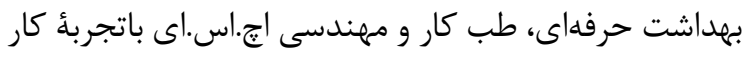

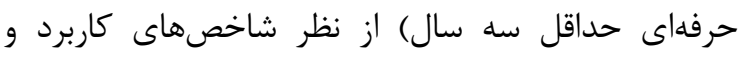

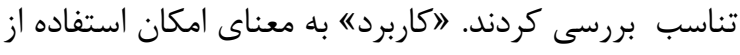

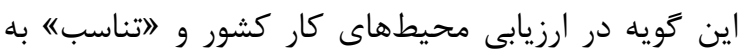

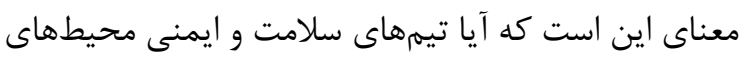

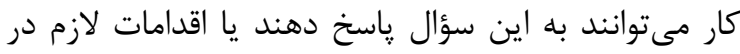

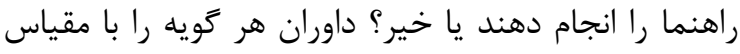

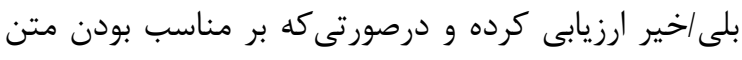

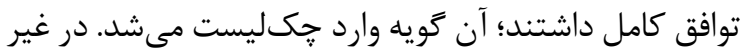
اين صورت يعنى اكر نظر حداقل يك داور مبنى بر لزوم تغيير

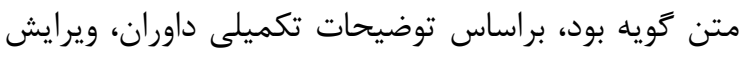

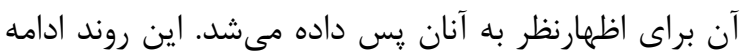

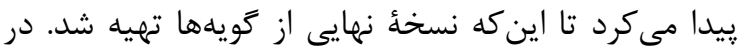
طى اين فرايند، داوران نسبت به نتيجه داورى يكديكر

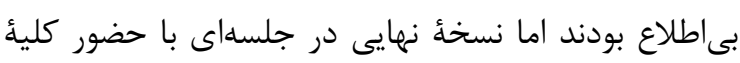
صاحبنظران، ويرايش نهايى شد.

براى تعيين وزن هر كويه، ابتدا هر يك از آنها در هيئتى متشكل از جهار نفر از صاحبنظران از تخصصهاى آموزش

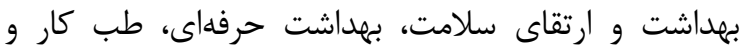

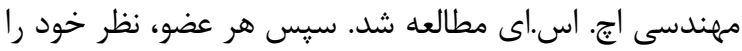

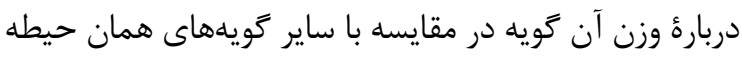
از • تا • ا اعلام مى كرد. در هر دور ميانكين و انحراف معيار

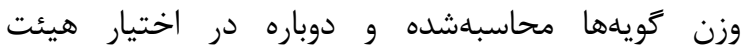
صاحبنظران قرار مى كرفت. در صورت مشاهدة انحراف معيار جشمخير، اعضا دوباره وزن دهى رَى را تكرار مى صى صردند.
مطالعات نشان مىدهند كه بيش از نيمى از مركهاى

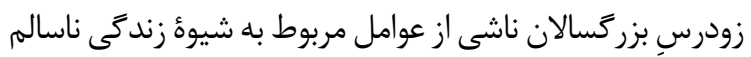

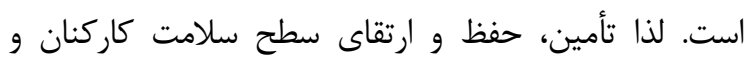
تأثيركذارى بر شيوه زندكى آنها اهميت فوقالعادهاى داري سارد

در دهdهاى اخير، رويكردها از سوى عوامل خطر فردى و

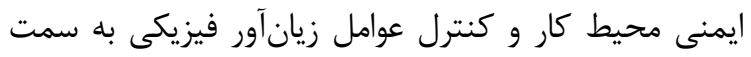

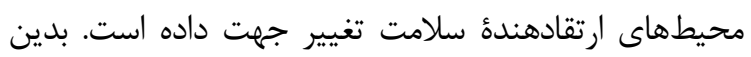

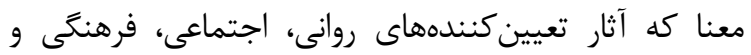
سياسى بر سلامت كاركنان، مديران، خانوادهها و جامعه مدنظر

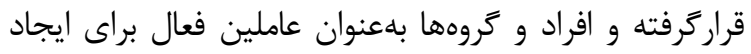
تغيير در محيط و سياستهاى حاكم شناسايىشدهاند. براساس اين رويكرد، ايجاد اين نوع محيطها، مسئوليت تمام ذىنفعان است (1-1 ا). در محيطهاى كار ارتقادهنده سلامت، كاركنان

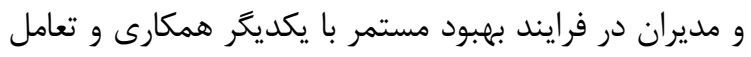
دارند و در راستاى حفاظت و ارتقاى سلامت و ايمنى كاركنان

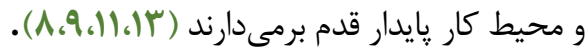

شيوههاى كار و زندگى افراد در اساس با گسترهٔ فعاليت و ارزشهاى شخصى و اجتماعى آنها ارتباط دارد. لذا، لذاء

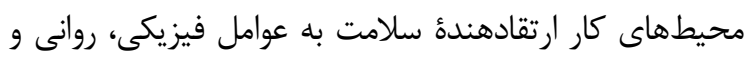
اجتماعى و همجنين كنش متقابل افراد و محيطشان توجه

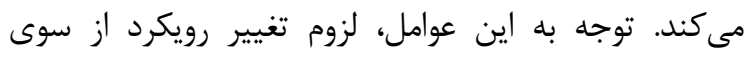

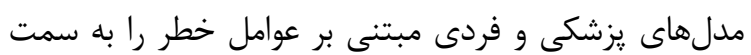
مدلهاى جامع و اجتماعى مطرح كرده است (1،9، (1). مدلهاى مختلفى در جهت ارزيابى محيطهاى كار

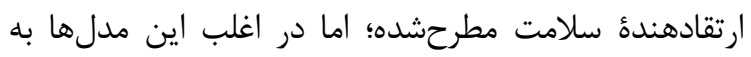
جنبههاى ارتقاى سلامت و شيؤ زندكى كمتر توجه شده است. در اين مطالعه، مدل محيط كار ارتقادهنده سلامت إن

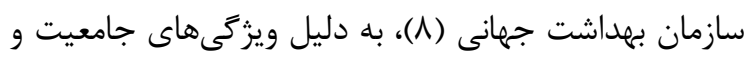

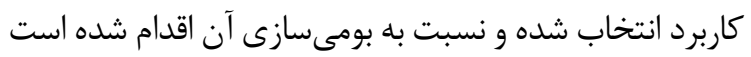

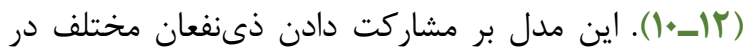
مراحل كسب تعهد و جلب حمايت، ارزيابى، اولويتبندى،

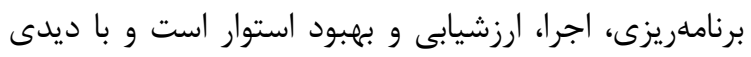

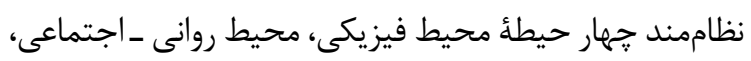

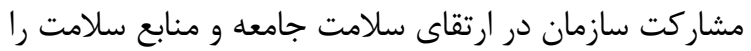

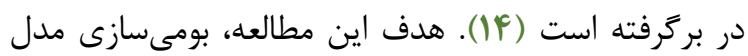


Sphericity معنى دارى دارد يا خير. درصورتى كه عاملهاى استخراجشده

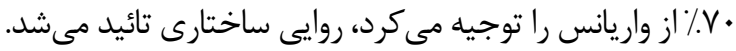
براى سنجش پايايى ابزار، دو روش يايايى همسانى

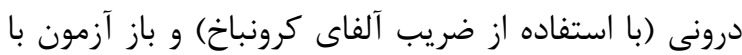

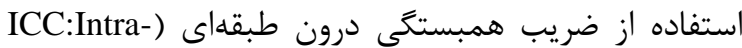
(class correlation coefficient

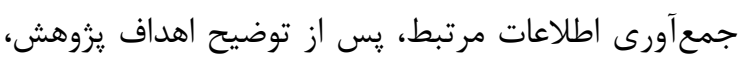

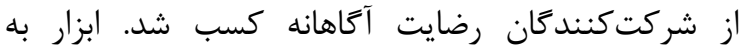
كروههاى هدف يزوهش ارائه شد كه آن را تكميل كردند.

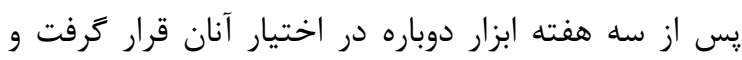

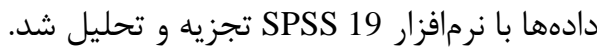
تدوين راهنماى اجر ايى مدل محيط كار ارتقادهندهُ سلامت راهنماى مدل محيط كار ارتقادهنده سلامت به شيوء

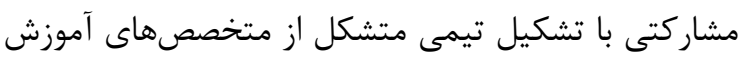
بهداشت و ارتقاى سلامت، بهداشت حرفهاى، طب كار و و مهندسى اج. اس.اى با تجربؤ كار حرفهاى و نمايندكان

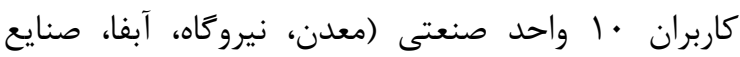

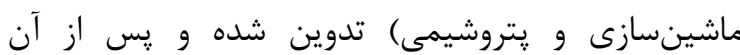
״يشنويس راهنماى مدل همراه جكليستهاى تدوينشده در نشستى با حضور مديران واحدهاى محيط كار و وارئ

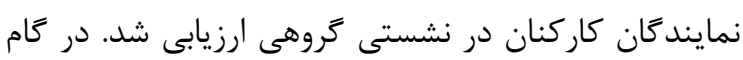
بعدى، تمام نظرات جمعبندى شده و تغييرات ييشنهادى

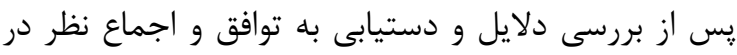

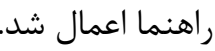

نهايى سازى ابزار و راهنماى محيط كار ارتقادهنده سلامت

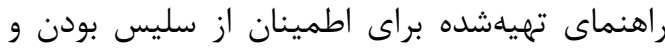

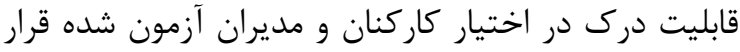

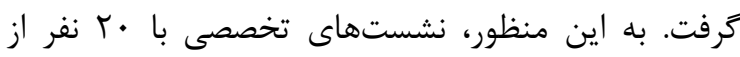
مديران واحدهاى محيط كار و نمايندكان كاركنان از

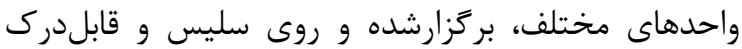
بودن كويهها و شيوههاى عملياتى كردن مراحل مدل و و نمونههاى موردى تجربهشده بحث شد. نقطه نظرهاى كاركنان و مديران را گروه تحقيق بازبينى و براساس آن راهنما ويرايش شد. ولد مديران
براى بررسى روايى صورى و روايى محتواى كيفى، براساس تنوع، محيطهاى كار وابسته به وزارت نيرو و وزارت صنعت، معدن و تجارت شناسايى شدند. از اين محيطها، از هر حيطؤ كارى اصلى يك واحد صنعتى در نظر كرفتهشده و بـانه مطالعه دعوت شد. شرط ورود اين واحدها به مطالعه، اعلام آمادگى مديران محيطهاى كار و همكارى مناسب مسئولين با كروه تحقيق بود. اين فرايند با هماهنتى روساى محيطهاى

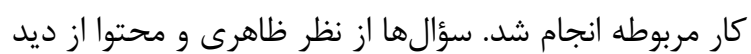
شركت كنندًان بررسى شده و اصلاحات لازم انجام شد.

بهمنظور بررسى كمّى روايى محتوا، براى اطمينان از

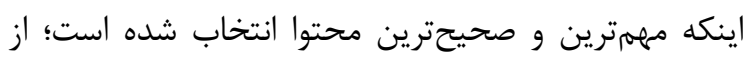
شاخص نسبت روايى محتوا (CVR:Content Validity Ratio)

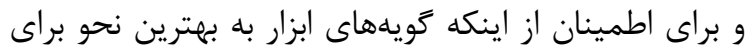

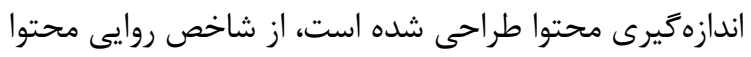
(CVI: Content Validity Index) شاخص نسبت روايى محتوا •1 نفر از متخصصان در

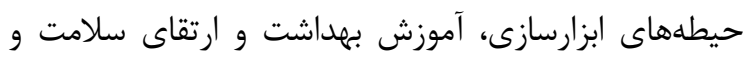
بهداشت حرفهاى به ضرورت زويهها براساس طيف سهبخشى إنشى ليكرت اضرورى است"، المفيد است ولى ضرورى نيست" و

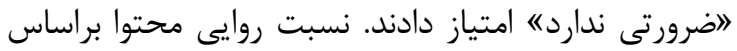

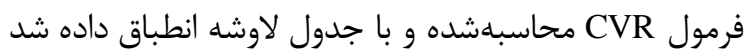

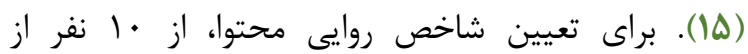
متخصصان درخواست شد كه به هريك از گويهها براساس سه آه معيار "مربوط بودنه، "واضح و شفاف بودن" و " اسادگى و

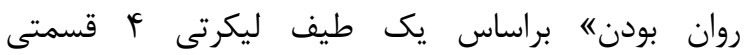

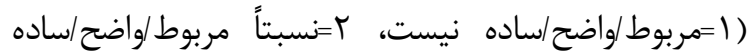

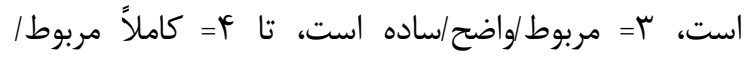
واضح/ساده است، امتياز دادند. شاخص روايى محتوا براساس فرمولCVI محاسبه شد. يذيرش روايى سؤالات براساس نمرءٔ

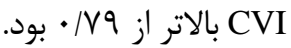
روايى ساختارى ابزار نيز با استفاده از روش تحليل

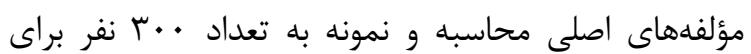
تحليل عاملى در نظر كرفته شد. آزمون كفايت نمونهگيرى KMO: Kaiser-Meyer-Olkin براى مناسب بودن حجم

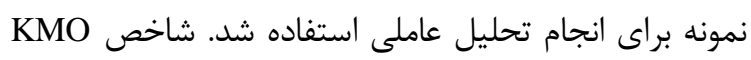

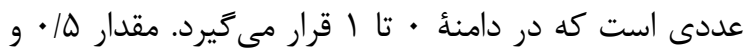
بيشتر بدين معناست كه دادههاى مدنظر براى تحليل عاملى الى

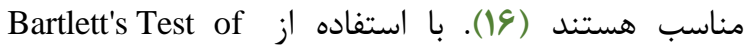


روايى و يايايى لازم را دارد و ابزار مناسبى براى سنجش

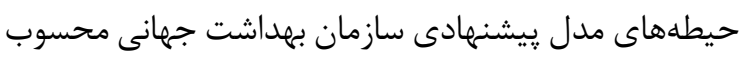
مىشود. در بررسى روايى محتوا، CVR هر تويه كه از عدد

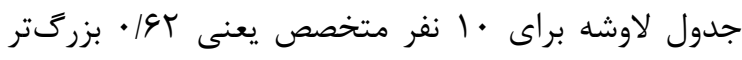

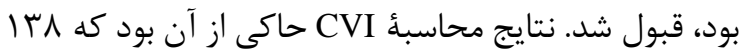

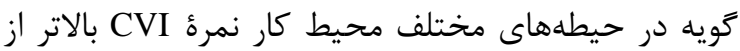

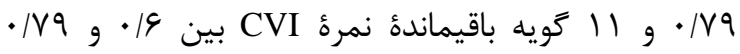

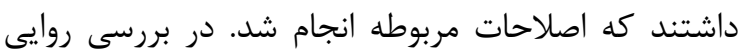
ساختارى، KMO تمام عوامل بيشتر از • •ه/ بود و درصد برد واريانس تبيين شده نشان مىدهد، روايى ساختارى در

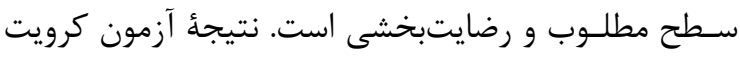
بارتلـت نيز از نظر آمارى معنى دار بود (جدول ؟ r).

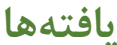
نتايج مربوط به بومىسازى ابزار و تدوين راهنماى اجر ايى در دو بخش ذيل ارائه مىشود: بومىسازى ابزارهاى مدل محيط كار ارتقادهندهُ سلامت جكىليستهاى ارزيابى حيطههاى مختلف محيط كار

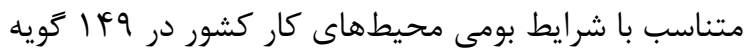
تهيه شد و هيئت متخصصان از نظر شاخصهاى كاربرد و تناسب به آن امتياز دادند. در جدول شماره أ اوزن مرتبط بأ حيطههاى محيط كار ارتقادهنده سلامت آورده شده است. نتايج بررسى ابزار از نظر روايى و يايايى نشان داد كه

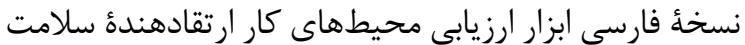

جدول ا. وزن حيطههاى محيط كار ارتقادهندهُ سلامت

\begin{tabular}{|c|c|c|c|}
\hline انحراف معيار & ميانكَين & عوامل & حيطهها \\
\hline $1 / r$ & $9 / 0$ & رعايت قوانين كار & \multirow{7}{*}{ 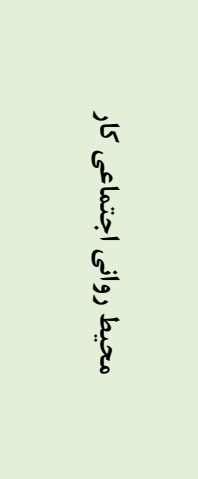 } \\
\hline$\cdot / V$ & $\wedge$ & فرهنَّ سازمانى & \\
\hline $1 / 1$ & $V / \Delta$ & سبك مديريت و رهبرى & \\
\hline $1 / 1$ & $V / V$ & تعادل كار و زندگى & \\
\hline $1 / f$ & v & توسعه مهارتهاى زندكى & \\
\hline 1 & $\wedge$ & امنيت شغلى /رضايت شغلى & \\
\hline$\cdot 19$ & V/Q & جابهجايى/ غيبت از كار & \\
\hline .19 & $V / \Delta$ & ارتقاى فعاليت فيزيكى در محيط كار & \multirow{5}{*}{ 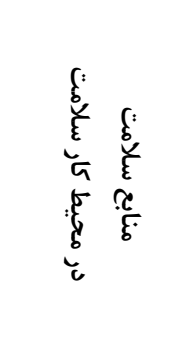 } \\
\hline $1 / \pi$ & $V / 1$ & ارتقاى تغذية سالم در محيط كار & \\
\hline$\cdot 11$ & $\Lambda / 1$ & ارتقاى محيط كار عارى از دخانيات & \\
\hline 1 & $V / f$ & مديريت استرس در محيط كار & \\
\hline$\cdot 10$ & $V / r$ & خدمات تشخيص و درمان & \\
\hline $1 / 1$ & $V / 1$ & مسئوليتيذيرى و مشاركت اجتماعى سازمان & है है है \\
\hline$\cdot 11$ & $v$ & 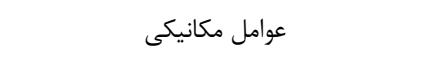 & \multirow{5}{*}{$\begin{array}{l}\xi \\
6 \\
6 \\
6\end{array}$} \\
\hline . & $\wedge$ & عوامل بيولوزيك & \\
\hline$\cdot / 9$ & $V / 1$ & 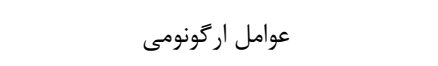 & \\
\hline$\cdot / 1$ & $V / r$ & عوامل فيزيكى & \\
\hline . & $\wedge$ & عوامل شيميايى & \\
\hline
\end{tabular}


جدول r. روايى ساختارى حيطه هاى مختلف مدل محيط كار ارتقادهندهُ سلامت

\begin{tabular}{|c|c|c|c|c|}
\hline$\%$ of Variance & Bartlett's Test & Kaiser-Meyer-Olkin Measure & 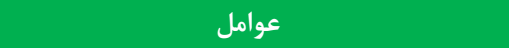 & حيطه \\
\hline$V \cdot / D F$ & $\cdot 1 \cdot 1$ & $\cdot / \Delta r$ & رعايت قوانين كار: آزادى عمل در كار & \multirow{14}{*}{ 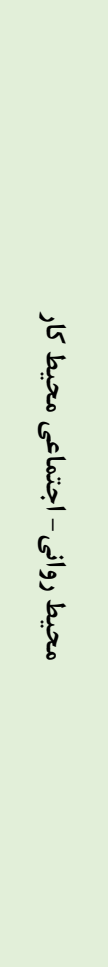 } \\
\hline VT/QG & $\cdot 1 \cdot v$ & $\cdot / \Delta \Delta$ & رعايت قوانين كار: بازخورد شغل (داخلى و خارجى) & \\
\hline$\Lambda / / F$. & $\cdot 1 \cdot r$ & $\cdot \mid \Delta \Lambda$ & رعايت قوانين كار: تنوع / شفافيت وظايف & \\
\hline$V Y / 99$ & $\cdot 1 \cdot 1$ & $\cdot 10$ & رعايت قوانين كار: هويت و اهميت وظايف & \\
\hline$V V / G Y$ & $\cdot 1 \cdot 1$ & $\cdot / \Delta r$ & رعايت قوانين كار: اضافه بارى/ كم بارى روانى & \\
\hline$\Lambda \Lambda / F$ & $\cdot 1 \cdot 1$ & $\cdot / \Delta \Lambda$ & رعايت قوانين كار: آموزش و ارتقا & \\
\hline$\Lambda \mu / \Lambda$. & $\cdot 1 \cdot 1$ & $\cdot|\Delta|$ & رعايت قوانين كار: تعهد سازمانى & \\
\hline$\vee q / 1 r$ & $\cdot 1 \cdot r$ & $\cdot|9|$ & رعايت قوانين كار: برنامةٔ زمانى كار & \\
\hline$\wedge \Delta / \wedge)$ & $\cdot 1 \cdot r$ & $\cdot / V T$ & فرهنَسازمانى & \\
\hline$M / / F$. & $\cdot / \cdot r$ & $\cdot \mid \Delta \Lambda$ & سبك مديريت و رهبرى & \\
\hline $99 / \pi q$ & $\cdot 1 \cdot .1$ & $\cdot / r$ & ت ت تعادل كار و زندگى & \\
\hline $91 / \Delta \wedge$ & $\cdot \cdot r$ & $\cdot / 0$ & توسعd مهارتهاى زندگى & \\
\hline VN/9T & . & $\cdot \operatorname{lat}$ & 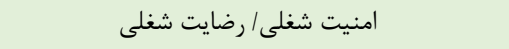 & \\
\hline$\wedge \Delta / \wedge)$ & $\cdot 1 \cdot \cdot 1$ & $\cdot / V T$ & جابهجايى/ غيبت از كار & \\
\hline$V \Delta / r)$ & $\cdot 1 \cdot \cdot 1$ & $\cdot 19$ & ارتقاى فعاليت فيزيكى در محيط كار & \multirow{5}{*}{ 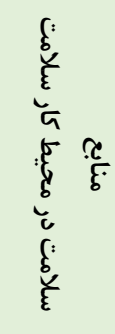 } \\
\hline$\Lambda \kappa / \Lambda$. & $\cdot 1 \cdot \cdot 1$ & $\cdot|\Delta|$ & ارتقاى تغذئ سالم در محيط كار & \\
\hline$\Lambda \cdot / 9 \Delta$ & $\cdot / \cdot r$ & $\cdot 109$ & ارتقاى محيط كار عارى از دخانيات & \\
\hline v৭/Ir & $\cdot 1 \cdot \cdot 1$ & $\cdot|9|$ & مديريت استرس در محيط كار & \\
\hline$\wedge 9 / 1 \wedge$ & $\cdot 1 \cdot 9$ & $\cdot \mid q 4$ & خدمات تشخيص و درمان & \\
\hline$V \psi / 9 \varphi$ & .1 .94 & $\cdot 10$ & مسئوليت يذيرى و مشاركت اجتماعى سازمان & 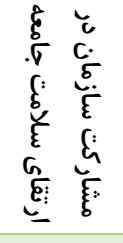 \\
\hline VN/9T & $\cdot / \cdot 1$ & $\cdot$. & 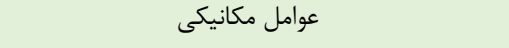 & \multirow{4}{*}{$\begin{array}{l}5 \\
6 \\
6 \\
6\end{array}$} \\
\hline$\Delta \Delta / \Gamma)$ & $\cdot / \cdot 1$ & $\cdot / 0$ & عوامل بيولوزيك و شيميايى & \\
\hline$V \Delta / T)$ & $\cdot 1 \cdot 1$ & $\cdot 19$ & 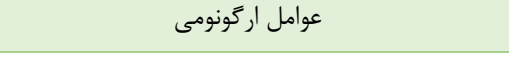 & \\
\hline$\vee q / \uparrow \Delta$ & $\cdot 1 \cdot r$ & $\cdot 199$ & عوامل فيزيكى & \\
\hline
\end{tabular}

شدهاند، ميزان آلفا كمتر از V/ • بود كه با حذف اين گويهها،

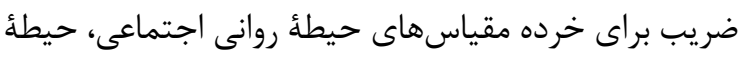

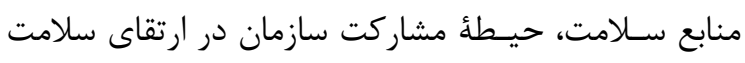
جامعه شامل مسئوليتيذيرى و مشاركت اجتماعى سازمان

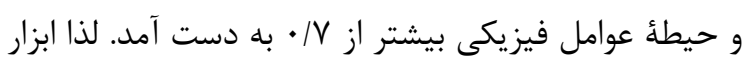

يايايى ابزار براساس دو روش یايايى همسانى درونى و آزمون

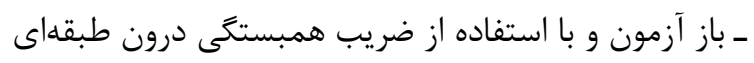

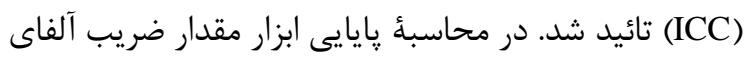

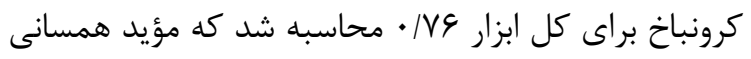

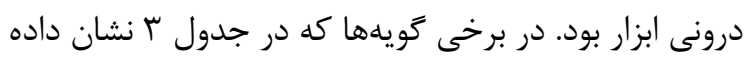


مكانيكى، بيولوزيك، اركونومى، فيزيكى و شيميايى) نهايى

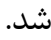

\section{تدوين راهنماى اجرايى مدل محيط كار ارتقادهندة}

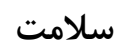

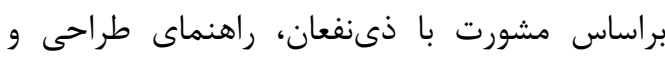

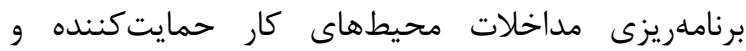
ارتقادهندة سلامت و ايمنى شامل عناوين زير طراحى شد:

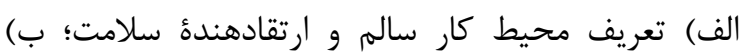

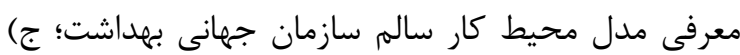
فرايندها و كامهاى ايجاد محيط كار ارتقادهندهٔ سلامت

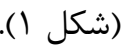

همسانى درونى رضايت بخشى داشت و از همبستخى درونى

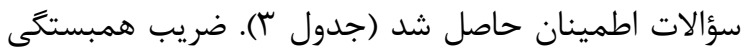
درون گروهى حاصل از آزمون ـ باز آزمون با سه هف هفته فاصله،

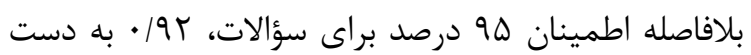
آمد كه نشاندهندة يذيرفتنى و مناسب بودن تكراريذيرى

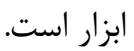

درنهايت، جكىليستهاى ارزيابى تهيهشده در جهار حيطهُ 1.

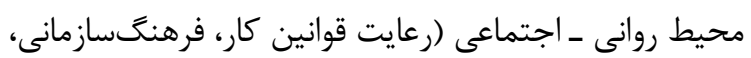

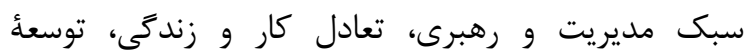

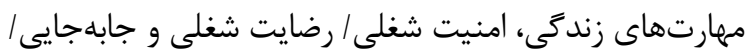

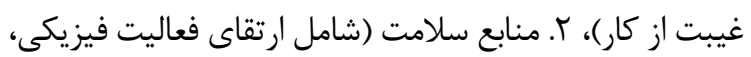

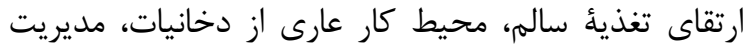

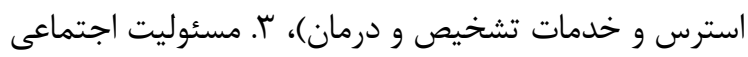

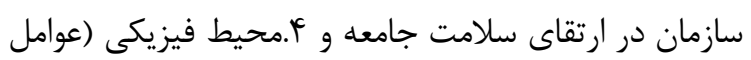

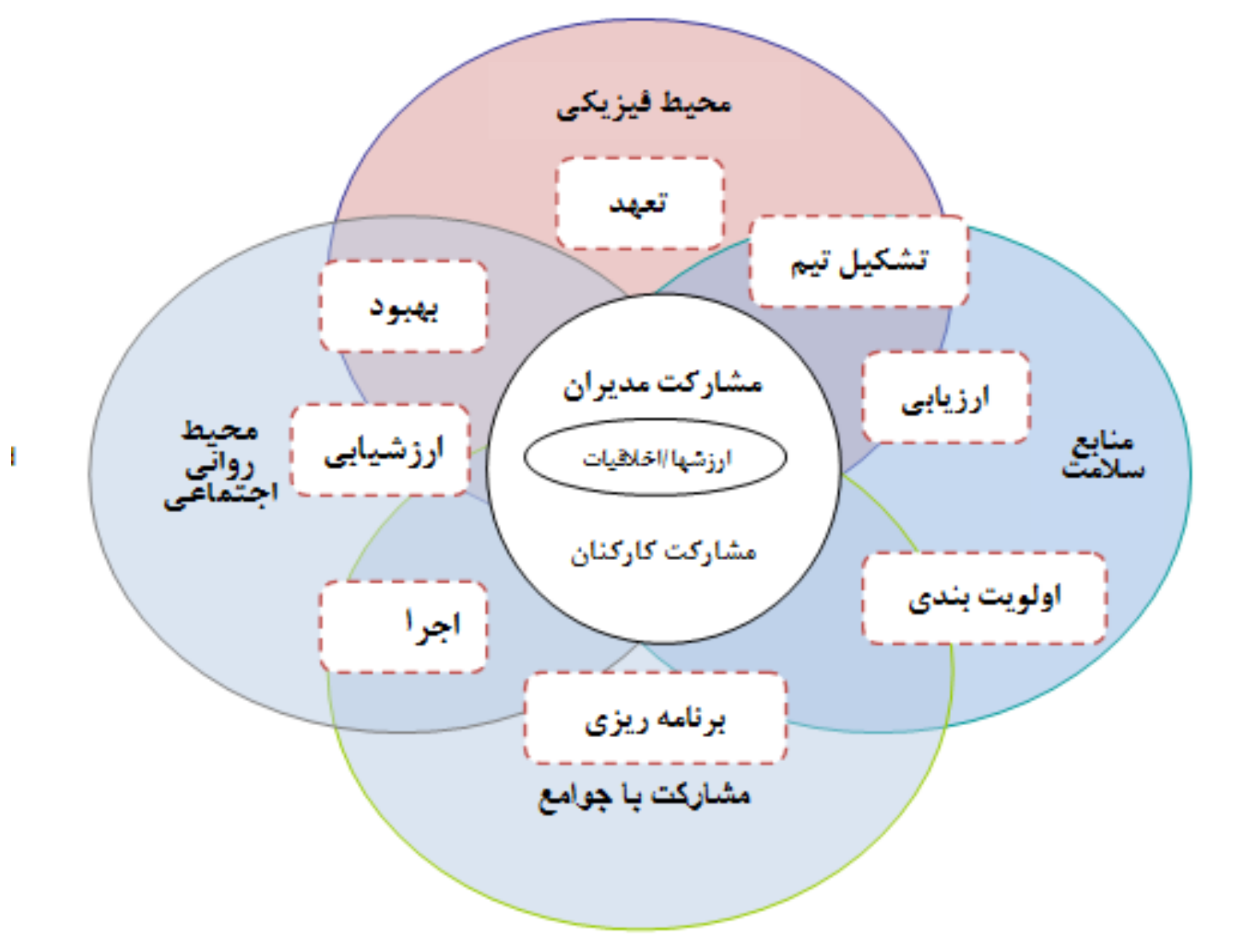

شكل 1. فرايندها و گَامهاى ايجاد محيط كار ارتقادهندهُ سلامت 
جدول ب. يايايى حيطههاى مختلف مدل محيط كار ارتقادهندهُ سلامت

\begin{tabular}{|c|c|c|c|c|}
\hline آلفاى كرونباخ يس از حذف حذيه & حذف تويه & 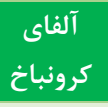 & عوامل & ميطه \\
\hline$\cdot / v$ & $* 1-1-1$ & .190 & رعايت قوانين كار: آزادى عمل در كار & \multirow{14}{*}{ 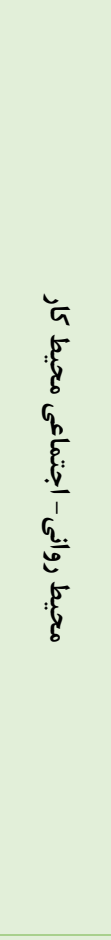 } \\
\hline.$V T$ & $* * r-r-1$ & $.1 \Delta \Delta$ & رعايت قوانين كار: بازخورد شغل (داخلى و خارجى) & \\
\hline$\cdot / v 9$ & $* * * r-r-1$ & .199 & رعايت قوانين كار: تنوع / شفافيت وظايف & \\
\hline.$/ v$ & &.$/ v$ & رعايت قوانين كار: هويت و اهميت وظايف & \\
\hline$\cdot / N F$ & & $\cdot / \mathrm{VF}$ & رعايت قوانين كار: اضافه بارى/ كم بارى روانى & \\
\hline.$N \cdot$ & &. $\mathrm{V} \cdot$ & رعايت قوانين كار: آموزش و ارتقا & \\
\hline$\cdot / V T$ & & $\cdot / V T$ & رعايت قوانين كار: تعهد سازمانى & \\
\hline$\cdot / V 1$ & & $\cdot / 21$ & رعايت قوانين كار: برنامهٔ زمانى كار & \\
\hline$\cdot / V V$ & & $\cdot / V V$ & 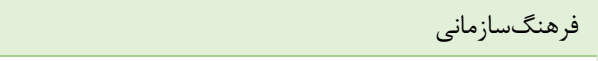 & \\
\hline$\cdot 119$ & $\begin{array}{c}* * * * 1 \cdot-1 \cdot-1 \\
\mid 1-1 \cdot-1 \\
\mid r-1 \cdot-1\end{array}$ & $\cdot \mid 9 \Lambda$ & سبك مديريت و رهبرى & \\
\hline$\cdot / N F$ & & $\cdot / N F$ & 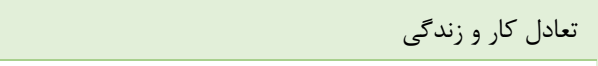 & \\
\hline$\cdot / v \cdot$ & & $\cdot / v$ & 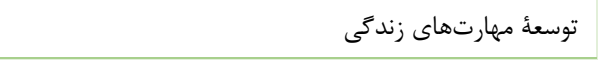 & \\
\hline$\cdot / v$ & & $\cdot / \mathrm{v}$ & 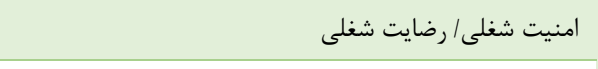 & \\
\hline - IAT & & $\cdot \operatorname{lat}$ & جابهجايى/ غيبت از كار & \\
\hline$\cdot 119$ & $\begin{array}{l}* * * * * * * 1-r \\
11-1-r\end{array}$ & .199 & ارتقاى فعاليت فيزيكى در محيط كار & \multirow{5}{*}{ 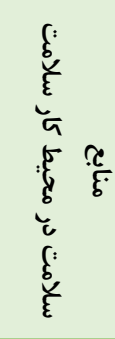 } \\
\hline.$/ 9 T$ & & $\cdot / 94$ & ارتقاى تغذئ سالم در محيط كار & \\
\hline$\cdot / \Lambda$ & & $\cdot 1 \Lambda$ & ارتقاى محيط كار عارى از دخانيات & \\
\hline$\cdot / A F$ & & $\cdot / \Lambda F$ & مديريت استرس در محيط كار & \\
\hline$\cdot / \mathrm{V} \Lambda$ & & $\cdot / v \wedge$ & خدمات تشخيص و درمان & \\
\hline.$/ 91$ & 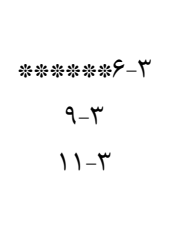 & .191 & 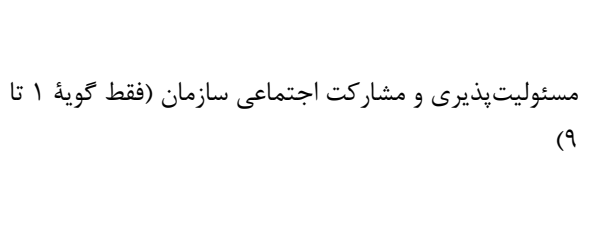 & 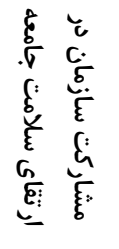 \\
\hline
\end{tabular}

\begin{tabular}{|c|c|c|c|}
\hline$\cdot / V r$ & $\cdot / V T$ & عوامل مكانيكى & \multirow{4}{*}{$\begin{array}{l}y \\
6 \\
6 \\
6\end{array}$} \\
\hline$\cdot / \mathrm{VI}$ & $\cdot / V 1$ & عوامل بيولوزيك و شيميايى & \\
\hline$\cdot / V \Delta$ & $\cdot / V \Delta$ & عوامل اركونوميك & \\
\hline$\cdot / N r$ & $\cdot / \mathrm{Vr}$ & عوامل فيزيكى & \\
\hline
\end{tabular}

* *آزادى عمل در كار وجود دارد (مثل آزادى نسبت به وضعيت عملكرد، كنترل كيفيت).

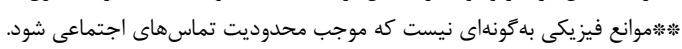

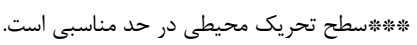

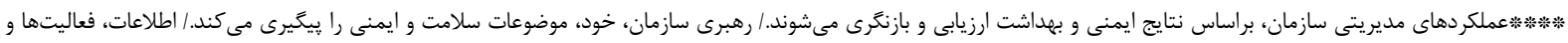

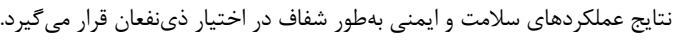

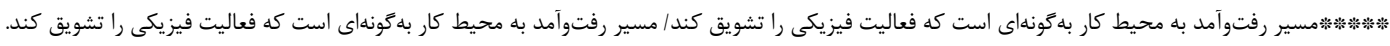

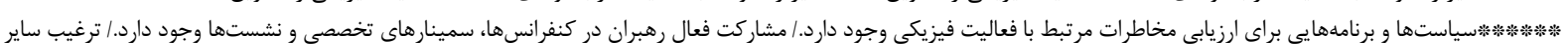

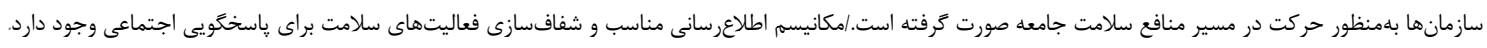


براساس اين معيارها انجام مى كيرد. از اين معيارها مىتوان به سهولت اجراى كار و امكان ايجاد تغيير (وجود راهكارهاى

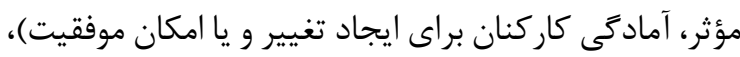

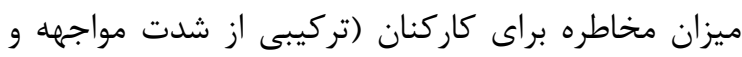

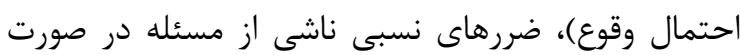
تداوم و حل نشدن آن و ملاحظات سازمانى اشاره كرد.

كام ينجم. برنامهريزى: براساس اولويتهاى حاصله،

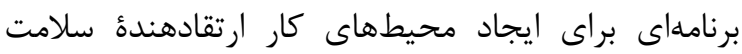
تدوين مىشود. بلويزه در سازمانهاى بزرى، در هر سال براساس برنامؤ بلندمدت سه تا ينجساله برنامئ سالانهاى تهييه

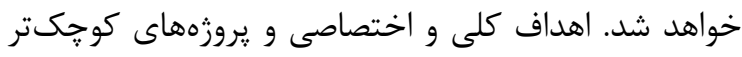
در اين برنامه مشخص مىشود. درنهايت، برنامئ عملياتى ونى

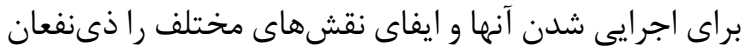

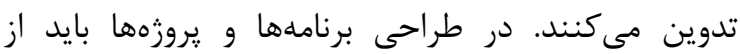

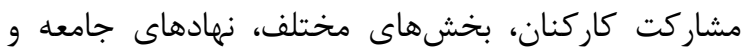
متخصصان خارج از سازمان بهره برده شود. طراحى مى بايد بهَّونهاى باشد كه منجر به ظرفيتسازى شود، انجام كار

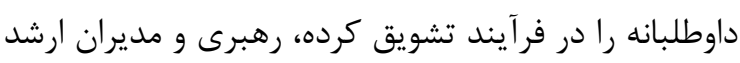

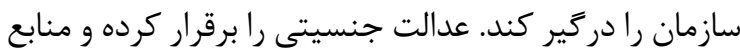

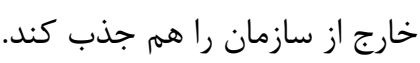

كام ششم. اجرا: در اين مرحله، برنامئ عملياتى با

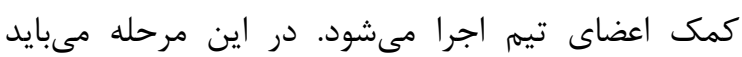

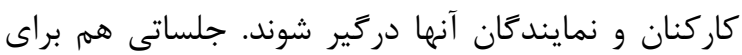

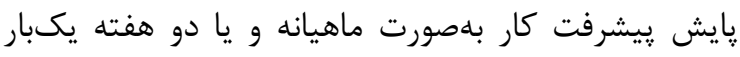
بر كزار مىشود.

كام هفتم. ارزشيابى: در اين مرحله، ميزان موفقيت و

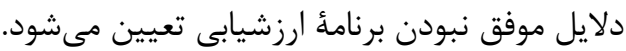

فرايندها شامل مشاركت كاركنان و مديران و توجه به ارزشها و اخلاقيات هستند. اين كامها در زير برشمرده

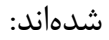

كام اول. بسيج و كسب تعهد، تشكيل تيم و هم/فزايى:

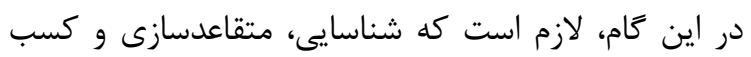

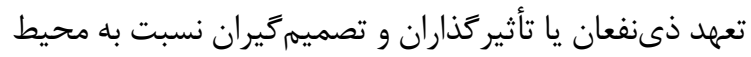
كار سالم و اجراى مداخلات محيطهاى كار حمايت كننده و

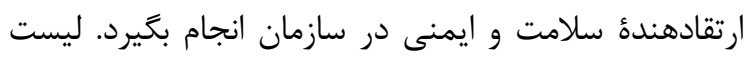
دستاندر كاران مؤثر بر ارتقاى سلامت و ايمنى (تأثير كذاران و و

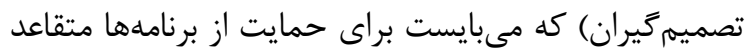

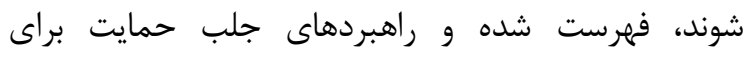
متقاعدسازى و جلب حمايت آنها طراحى و اجرا مى شوده. كام دوم. تشكيل تيم و همافزايى: در اين گام، تيم

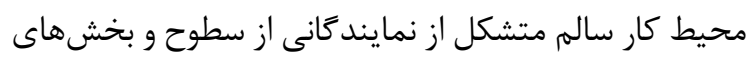

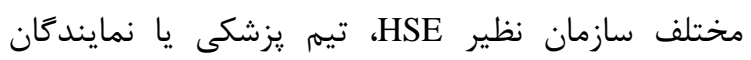

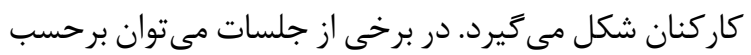

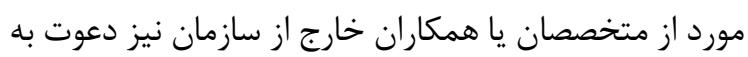

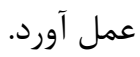
كام سوم. ارزيابى حيطههاى مدل محيط كار

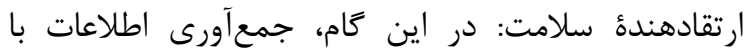
استفاده از جكليستهاى مدل، مشاهدهها و بازديدهاى

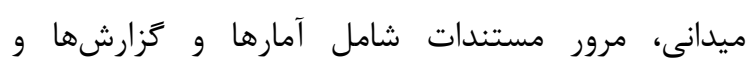
مصاحبههاى فردى و گروهى با افراد كليدى و كار كنان انجام

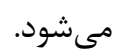
كام جهارم. اولويتبندى: پِّ از اينكه اطلاعات در زمينٔ حيطههاى مختلف محيط كار سالم جمعآورى شد، روى معيارهاى اولويتبندى توافق شده و اولويتبندى 
جدول Fا. ابزار ارزيابى محيط كار ارتقادهندهُ سلامت مبتنى بر مدل سازمان بهداشت جهانى

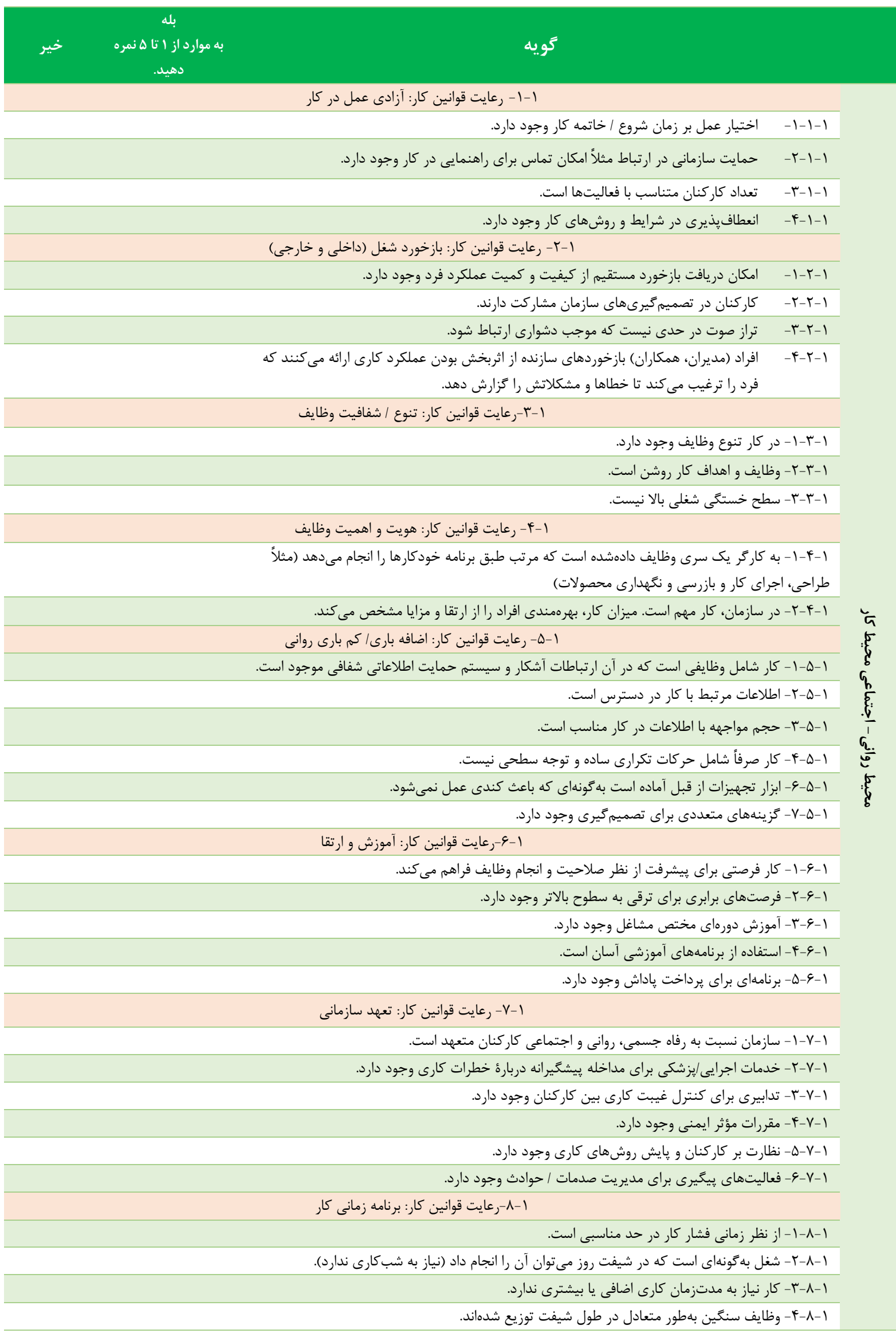


.

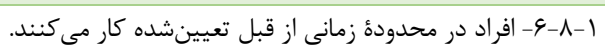

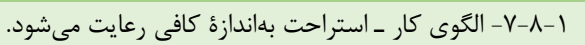

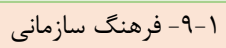

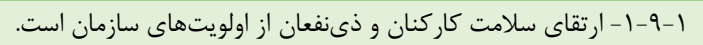

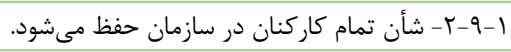

1

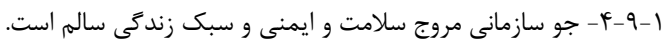

|-1

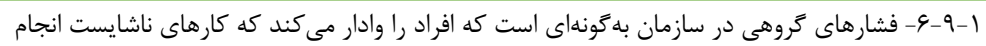

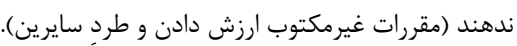

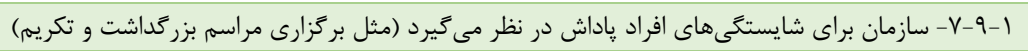

1- - إ سبك مديريت و رهبرى

|-1

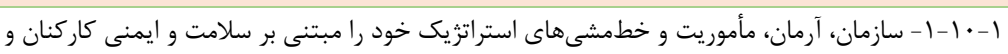

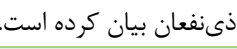

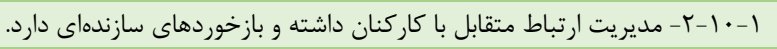

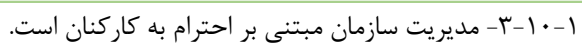

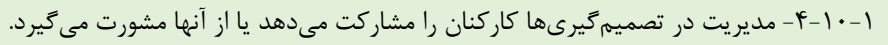

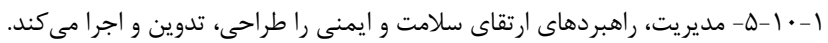

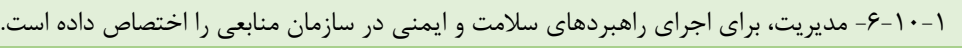

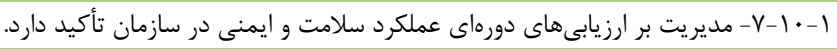

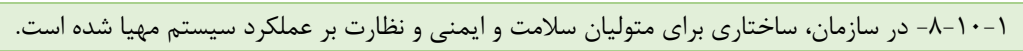

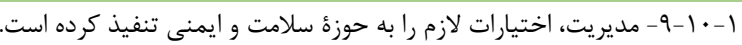

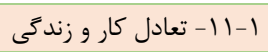

|-11-1 كاري، كارها در سازمان بهكونهاى است كه نيازى نيست كاركنان بهناجار ساعتهايى طولانىتر از شيفت

كارى، به فعاليتهاى مرتبط با كار ادامه دهند.

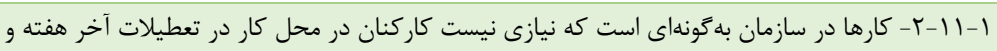
تعطيلات رسمى حضور داشته باشند.

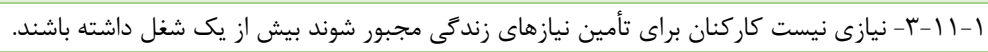

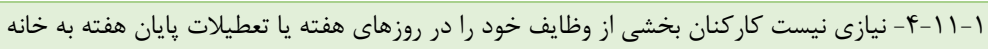

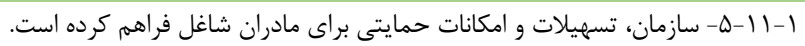

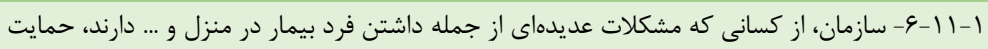

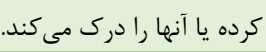

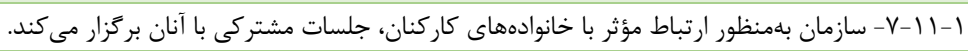

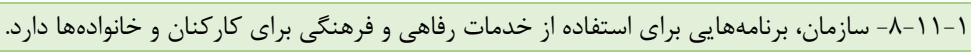

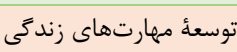

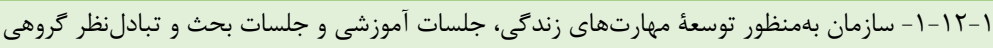

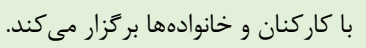

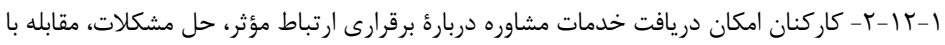

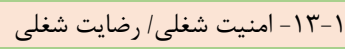

استرس و..., را دارند.

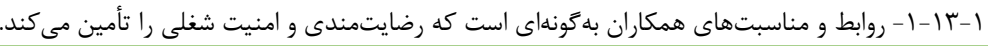

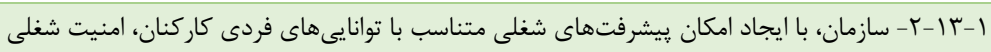

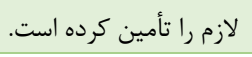

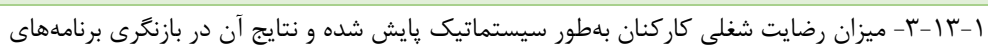
مديريتى سازمان مشهود است. مشان.

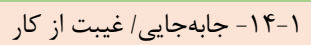




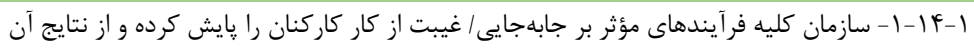

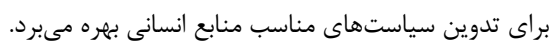

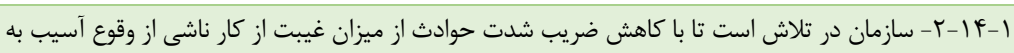

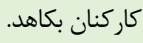

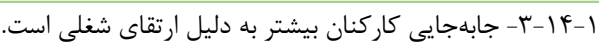

جدول ه. ارزيابى حيطة منابع سلامت در محيط كار

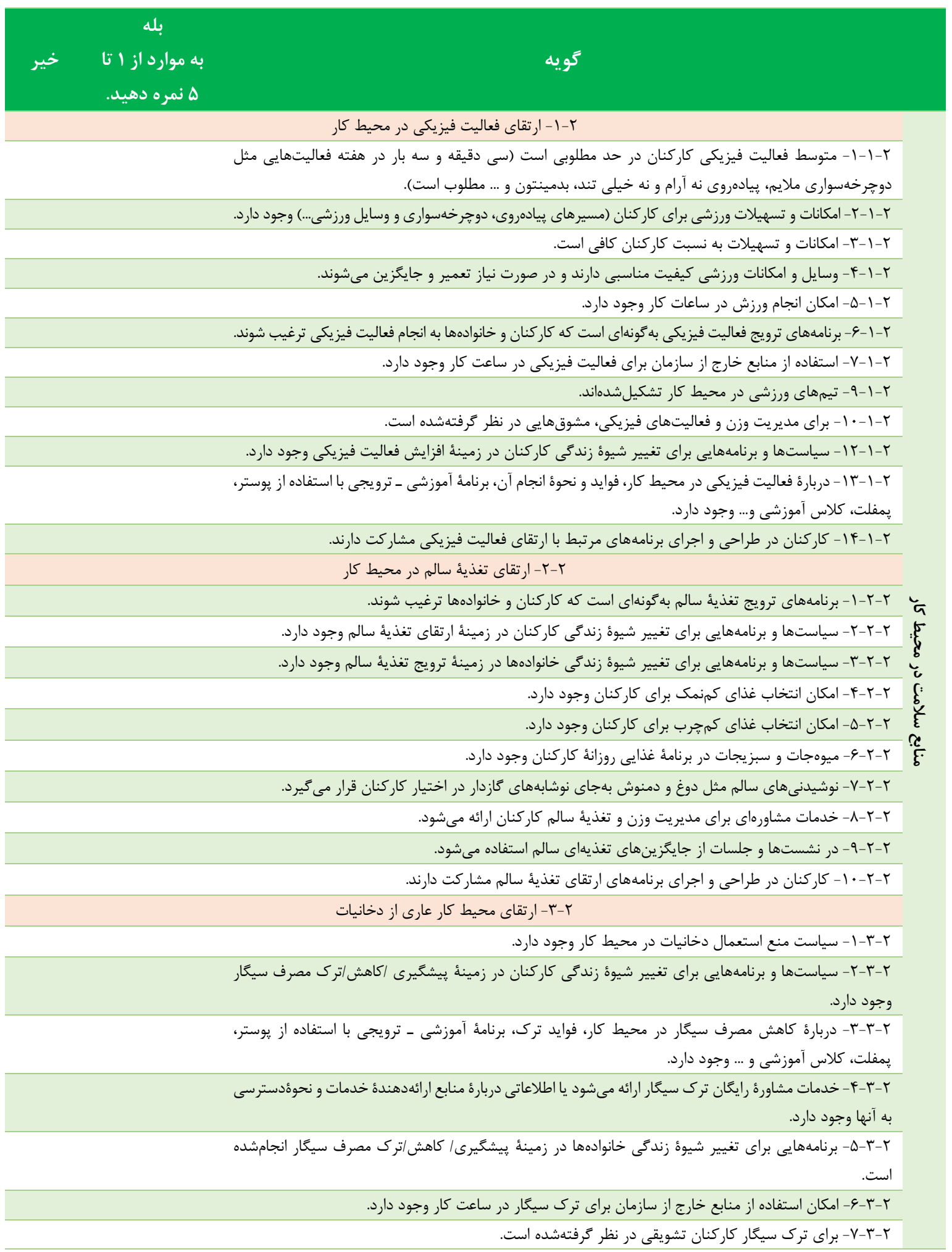




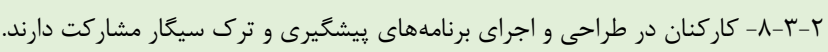

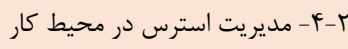

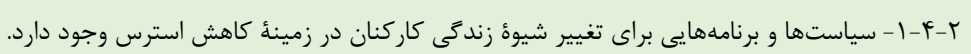

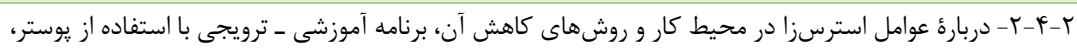

يمفلت، كلاس آموزشى و ... وجود دارد.

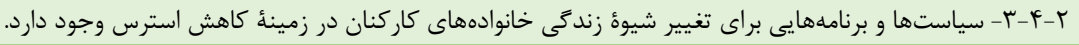

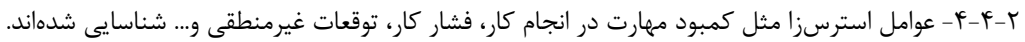

r

r-Y-Y

L

-

ا

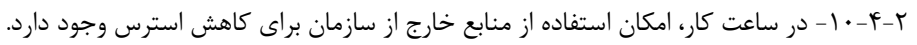

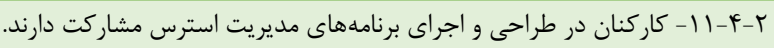

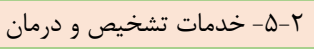

Y-Y- - - خدمات تشخيص و درمان مناسب و در دسترس براى كاركنان وجود دارد.

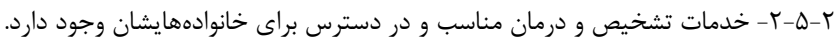

ا

مي شود-

مىشود.

مسئوليت پذيرى سازمان و روانى ـ اجتماعى جامعيت لازم را

ندارد.

در مقالهٔ بومىسازى مدل تعالى سازمانى بنياد ارويايى

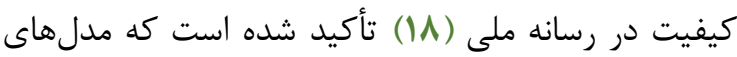

رايج، ياسخكَى نياز سازمانها در حوزههاى مختلف نيست ميت

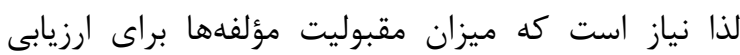
عملكرد از ديدگًاه خبركان بررسىشده، سيس راهن راهنماى ارزيابى عملكرد در حوزههاى مطالعه شده تدوين و نهايى

از جمله مدلهاى ارتقادهنده سلامت در محيط كار،

مدل كار سالم در ايران است كه با استناد به الزامات و نيازهاى استانداردهاى جهانى و ملى ملى موجود در زمان زمينه سلامت، ايمنى و بهداشت حرفهاى طرحريزى شده است. اين مدل از دو حوزه و هشت معيار و شانزده زير معيار تشكيل شده است كه در دو بخش عوامل توانمندساز و نتايج

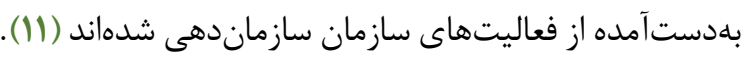
اين الكو نيز به كامهاى عملى به سمت مداخله ورود بيدا نكرده است. درنتيجه، ابزارهاى مطالعئ حاضر مى تواند خلأ موجود را بهعنوان راهنمايى عملياتى يركند و محققان،

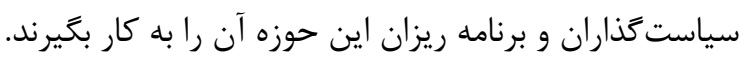

بحث

هدف از انجام مطالعة حاضر، بومىسازى مدل محيط

كار ارتقادهندهُ سلامت و تدوين راهنماى اجرايى آن است.

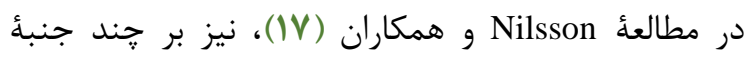
كليدى براى تدوين يرسشنامه در حوزه محيطهاى كار ارتقادهنده سلامت تأكيد شده است: دركير كردن گروههاى اصلى، تصميمَّيرى مشاركتى و ييروى از يك ساختار. اين

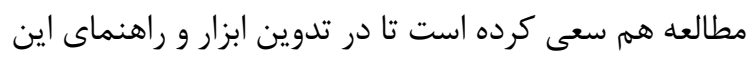
مدل از فرايند مشاركتى بهره گَيرد و گروه اصلى ذىنفع را

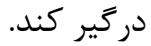

در مطالعهُ حاضر، روايى و پايايى ابزار با استفاده از

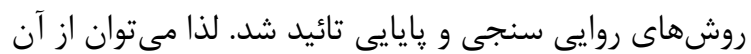
بهعنوان ابزار مناسبى در مطالعات مختلف بهره كرفت.

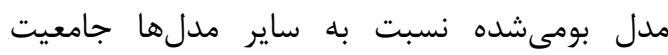

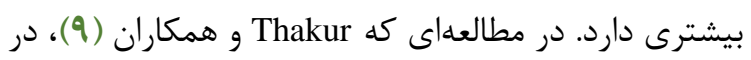

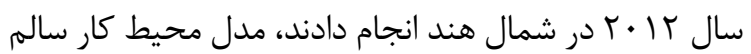
در سه حيطهُ محيط فيزيكى، روانى ـ اجتماعى و ارتقاى

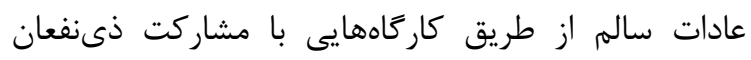

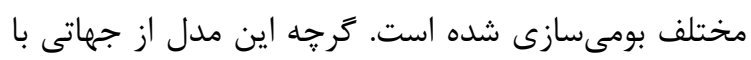
ابعاد مدل تدوينى مطالعة حاضر تشابه دارد؛ اما در ابعاد 


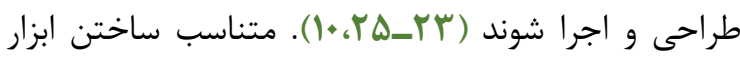

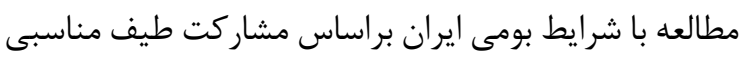
از ذىنفعان محيط كار و شناسايى دغدغههاى آنها مىتواند به موفقيت مداخلاتى كمك كند كه براساس اين راهنما اجرا

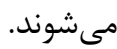

از نقاط قوت ديخر مطالعه مىتوان به انتخاب مدل و شيؤ عملياتى كردن آن اشاره كرد. اين مدل به علت توجه

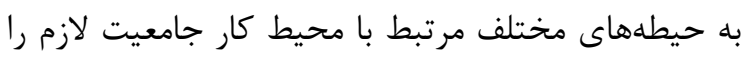

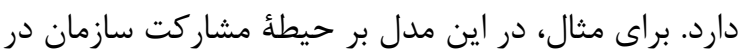
مسئوليت اجتماعى كه در مدلهاى ديكر كمتر به آن توجه شده است، تأكيد شد. از محدوديتهاى مطالعه، تعداد محدود نمايند محيطهاى كار و تعميم دادن آن به ساير محيطها است.

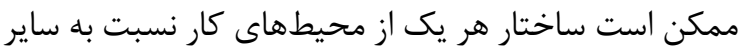

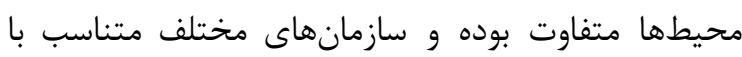
سطح آمادگىشان نتايج متفاوتى از بهكاركيرى اين مدل به إنهات

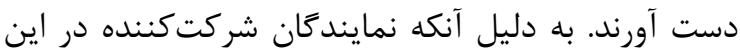

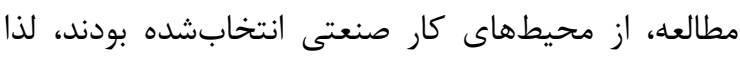

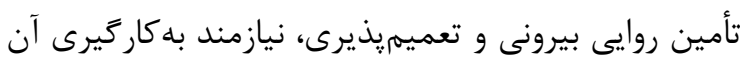
در محيطهاى كار غيرصنعتى است.

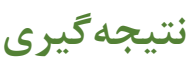

ابزار اين مطالعه مىتواند يائه ارزيابى مناسبى را از

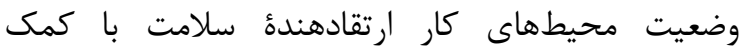
مجموعهاى از فرايندها و مؤلفههاى جهار كاركانه ارزيابى كندا.

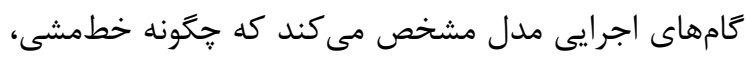

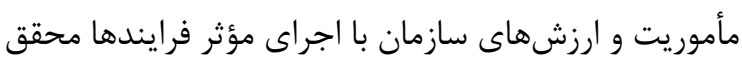

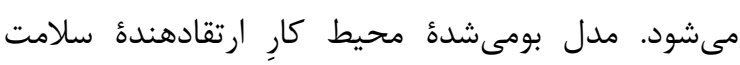

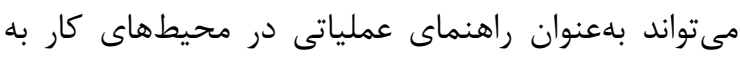
وسيله محققين، سياست گذاران و برنامهريزان به كار گرفته

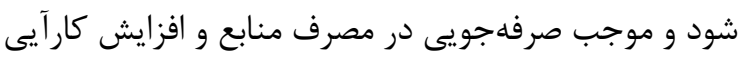

نويسندًان مراتب قدردانى خود را از مديران عامل، مسئولين HSE و كاركنان محيطهاى كار اعلام مى كنند كه در اين مطالعه مشاركت كردهاند. اين مقاله حاصل طرح

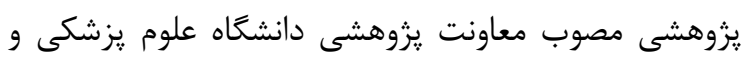

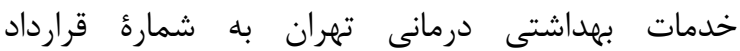

مدل كار سالم مركز مديريت بيمارىها نيز جهار كام دارد. اين كامها عبارتاند از: ا. ارزيابى (در سطح فرده، سازمان و جامعه)؛ r. برنامهريزى و مديريت (جلب حمايت آنايت رهبران، مديريت، تدوين اهداف و استراتزىها، تعيين منابع

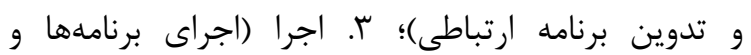

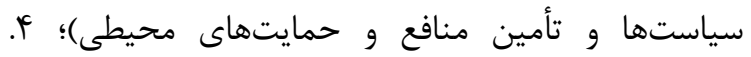

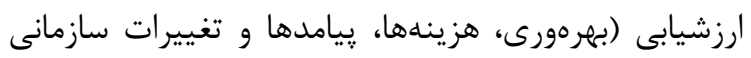

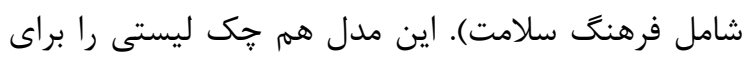
ارزيابى محيط كار ارتقادهنده سلامت يِيشنهاد كرده است است

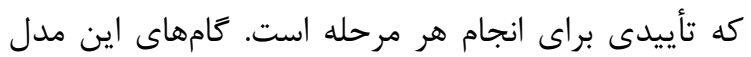
شباهت هايى با كامهاى مدل استفادهشده در اين مطالعه دام دارد. در نظر كرفتن منافع و حمايتهاى محيطى در مرحلئ اجرا

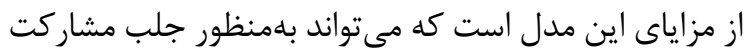

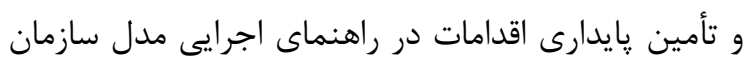

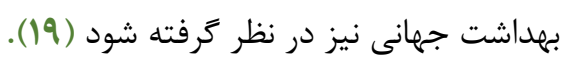
راهنماى ايجاد محيطهاى كار سالم بيشنهاد شده

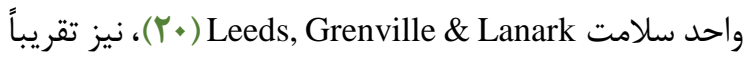

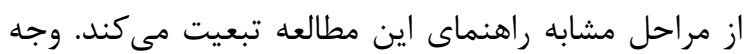

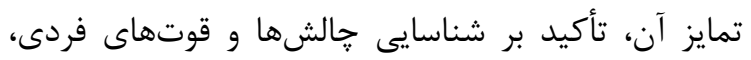

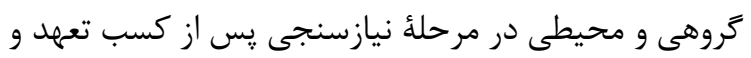
تشكيل تيم است.

در اين مطالعه، راهنماى طراحى و بر برنامهريزى

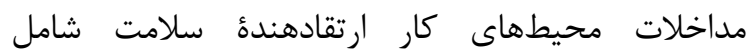
فرايندهاى مشاركت دادن كاركنان و مديران و توجه به آنهات

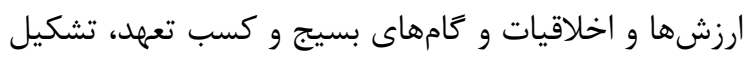
تيم و هم/افزايى، ارزيابى حيطههاى مدل محيط كار ارتقادهندة سلامت، اولويتبندى، برنائامهاريزى، اجرا و و

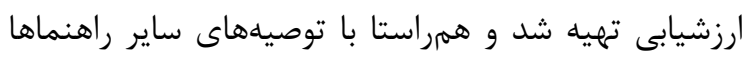

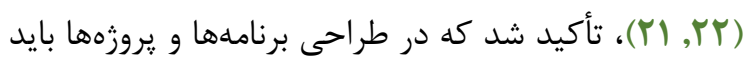

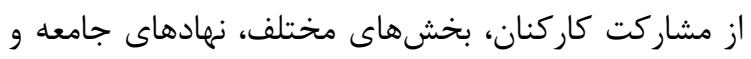
متخصصين خارج از سازمان بهره برده شود، رهبران و مديران

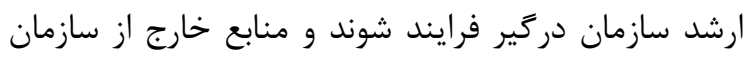

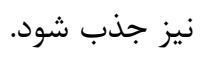
از نقاط قوت مطالعه مىتوان به جنبأ مشاركتى بودن

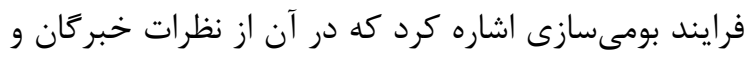

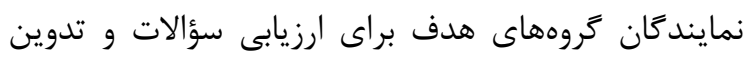

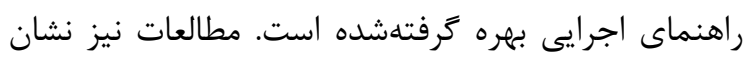
مىدهند كه مدلهاى ارتقاى سلامت در محيط كار زمانى كرانى

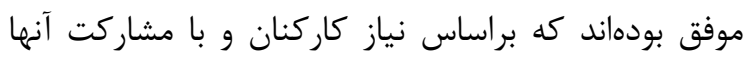




$$
\begin{aligned}
& \text { تعارض در منافع } \\
& \text { آمده است } \\
& \text { بين نويسندكان تعارضى در منافع گزارش نشده است. }
\end{aligned}
$$

\section{References}

1. World Health Organization. Milestones in health promotion: Statements from global conferences: Geneva: World Health Organization; 2009.

2. Robroek SJ, van Lenthe FJ, Burdorf A. The role of lifestyle, health, and work in educational inequalities in sick leave and productivity loss at work. International archives of occupational and environmental health. 2013;86(6):619-27 .https:// doi.org/10.1007/s00420012-0793-1 PMC3722458

3. Rongen A, Robroek SJ, van Lenthe FJ, Burdorf A. Workplace health promotion: a meta-analysis of effectiveness. American journal of preventive medicine. 2013;44(4):406-15 /10.1016/j.amepre.2012.12.007 PMid:23498108

4. Van Rijn RM, Robroek SJ, Brouwer S, Burdorf A. Influence of poor health on exit from paid employment: a systematic review. Occupational and environmental medicine. 2014; $71 \quad$ (4):295-301 https:// doi.org.1136/oemed-2013-101591 PMid:24169931

5. Robroek SJ, Schuring M, Croezen S, Stattin M, Burdorf A. Poor health, unhealthy behaviors, and unfavorable work characteristics influence pathways of exit from paid employment among older workers in Europe: a four year follow-up study. Scandinavian journal of work, environment \& health. 2013;39(2):125-33 https://doi.org /10.5271/sjweh.3319 PMid:22949091

6. Rafifar S, Damari B. Health Education and Promotion comprehensive System in Workplace. Tehran: Mehr Ravesh Publication; 2005.

7. Ministry of Health and Medical Education. National strategic plan on prevention and control of noncommunicable diseases and related risk factors in the Islamic Republic of Iran (1394 to 1404). Tehran: National Committee for Prevention and Control of NonCommunicable Diseases, 2015.

8. World Health Organization. Healthy workplaces: a model for action: for employers, workers, policymakers and practitioners. 2010.

9. Thakur JS, Bains P, Kar SS, Wadhwa S, Moirangthem P, Kumar R, et al. Integrated healthy workplace model: An experience from North Indian industry. Indian journal of occupational and environmental medicine. 2012;16(3):108 .https://doi.org/10.4103/0019-5278.11 1750 PMC3683177

10. Bahrami A, Rastkari N, Allahyari T. A Guide to Ergonomic Workplace Assessment. Tehran: Tehran University of Medical Science; 2012.

11. Motallebi M, Ghazi Mirsaeid A, Rafifar Sh. A comprehensive model of evaluating and improving the health and safety of the workplace (healthy work model): indicators and metrics Tehran: Mezrab; 2012.

12. Jafari MJ, Sadighzadeh A, Sarsangi V. Development and Psychometrics of "Safety Climate Assessment Questionnaire". Journal of Safety Promotion and Injury Prevention. 2013;1(3):123-33.
13. Taghdisi MH, Haghighi M, Alimohammadi I. Assessment health Safety and Environment culture in an oil Refinery Based on Geller Model. Journal of Health Education and Health Promotio. 2013;1(3):47-55.

14. Burton J. WHO Healthy workplace framework and model: Background and supporting literature and practices.World Health Organization, 2010.

15. Lawshe $\mathrm{CH}$. A quantitative approach to content validity. Personnel psychology. 1975;28(4):563-75. https://doi.org/10.1111/j.1744-6570.1975.tb01393.x

16. Cravens KS OE, Oishi S, Stewart JS. Workplace culture mediates performance appraisal effectiveness and employee outcomes: A study in a retail setting. Journal of Management Accounting Research. 2015;27(2):134 .https://doi.org/10.2308 /jmar-51169

17. Nilsson P, Andersson HI, Ejlertsson G, Blomqvist K. How to make a workplace health promotion questionnaire process applicable, meaningful and sustainable. Journal of nursing management. 2011;19(7):906-14.https://doi.org/10.1111/j.13652834.2011.01257.x PMid:21988438

18. Shams GH, Bolusar C. Indigeniztion of European Foundation for Quality Management Model in mass media. Journal of Public Administration Research. 2013;1 (2):109-24.

19. Center for Disease Control and Prevention. Workplace health promotion: CDC At a glance report. Georgia: Division of population health, Workplace health promotion program; 2016.

20. Healthy Workplace Team of the Leeds GLDHU. Brockville Canada: Healthy Workplace Guide; 2009.

21. Safety NIfO, Health. Essential elements of effective workplace programs and policies for improving worker health and wellbeing. National Institute for Occupational Safety and Health. 2008.

22. Work H. Guide to Promoting Health \&Wellbeing in the Workplace. Canberra, Australia: ACT Goverment; 2012.

23. Block G, Sternfeld B, Block C, Block T, Norris J, Hopkins D, et al. Development of Alive!(A Lifestyle Intervention Via Email), and its effect on health-related quality of life, presenteeism, and other behavioral outcomes: randomized controlled trial. J Med Internet Res. 2008;10(4):e43. https:// doi.org/10.2196/jmir.1112 PMC2629370

24. Rivilis I, Cole DC, Frazer MB, Kerr MS, Wells RP, Ibrahim S. Evaluation of a participatory ergonomic intervention aimed at improving musculoskeletal health. Am J Ind Med. 2006;49(10):801-10. https: //doi.org/10.1002/ajim.20382 PMid:16960887

25. Mills PR, Kessler RC, Cooper J, Sullivan S. Impact of a health promotion program on employee health risks and work productivity. Am J Health Behav. 2007;22(1):4553. https://doi.org/10.4278/0890-1171-22.1.45 